Deng, Z (in-press). Pedagogical content knowledge reconceived: Bringing curriculum thinking into the conversation on teachers' content knowledge. Teaching and Teacher Education.

\title{
Pedagogical Content Knowledge Reconceived: Bringing Curriculum Thinking into the Conversation on Teachers' Content Knowledge
}

(Please do not cite or quote without permission)

\author{
Zongyi Deng \\ National Institute of Education, \\ Nanyang Technological University \\ 1 Nanyang Walk, Singapore 637616 \\ Phone: (65) 67903978 \\ Fax: (65) 68968950 \\ E-mail: zongyi.deng@nie.edu.sg
}

\begin{abstract}
This article contributes to a reconceptualization of pedagogical content knowledge through exploring what is entailed in teachers' understanding of content within the framework of the institutional curriculum, with a central concern for the development of human powers (capacities or abilities, ways of thinking, understanding worlds). The contribution is made by way of a curriculum making framework and through examining the capabilities approach and Bildung-centered Didaktik. The central thesis is that a teacher necessarily interprets the content contained in the institutional curriculum, identifying its elementary elements and ascertaining its educational potential. The interpretation calls for curriculum thinking informed by a theory of content.
\end{abstract}

Keywords: Pedagogical content knowledge; content or subject matter; curriculum thinking; Didaktik; Bildung. 


\section{Introduction}

Originating from the effort of Lee Shulman and associates to address a "missing paradigm" in research on teaching and to professionalize teaching in the 1980s, pedagogical content knowledge (PCK) has become a highly popular and influential concept in the educational community. It has been used to inform policies on teacher certification, licensure examination and professional development (e.g., Haertel, 1991; Phelps \& Schilling, 2004; Shulman, 1986b, 1987). It has also been employed as a basis for designing teacher education and continuous professional development programs (e.g., Clermont, Krajcik, \& Borko, 1993; Grimmett \& MacKinnon, 1992; Loughran, Berry, \& Mulhall, 2012; Peterson \& Treagust, 1998). It too has been used in large scale international assessment studies on the effectiveness of teacher education programs (e.g., Blömeke, Felbrich, Müller, Kaiser, \& Lehmann, 2008; Schmidt, Blömeke, \& Tatto, 2011). Furthermore, the concept has spurred a significantly large body of empirical studies devoted to the investigation and elaboration of this concept in relation to teaching and teacher education, particularly in mathematics and science (e.g., Ball \& Bass, 2000; Lederman, Gess-Newsome, \& Latz, 1994; Loughran, Mulhall, \& Berry, 2004).

As a special kind of teachers' content knowledge that "embodies the aspects of content most germane to its teachability" (Shulman, 1986b, p. 9), PCK includes knowledge of pedagogical representations, of instructional strategies, and of students' prior knowledge and learning difficulties pertaining to the teaching of a particular topic to students of various backgrounds and experiences. With the marshalling of this knowledge and by way of pedagogical reasoning, a teacher transforms the content he or she possesses into pedagogical forms such as representations, instructional tasks, and classroom activities that make content comprehensible for students (Shulman, 1987; Wilson, Shulman, \& Richert, 1987).

Over the last three decades, the concept has been subject to numerous criticisms and has been modified, expanded, or further articulated by researchers (see Depaepe, Verschaffel, 
\& Kelchtermans [2013] for a useful review). However, despite being questioned by several scholars (e.g., Deng, 2007a; Deng \& Luke, 2008; Thornton and Barton, 2010), the underlying assumption that a teacher necessarily transforms his or her content knowledge of an academic discipline into pedagogical forms still remains taken for granted. This assumption tends to ignore the fact that in classroom what a teacher works with is the content of a school subject in the institutional curriculum-i.e., the curriculum provided to a school system. This content results from a selection, organization, and transformation of knowledge, skills and values from the related academic discipline or disciplines and other sources for social, cultural and educational purposes (see Deng, 2009; Karmon, 2007). As a result of such a taken-forgranted assumption, what a teacher needs to know and be able to do with respect to the content in the institutional curriculum remains largely unexplored and undertheorized in the PCK literature.

This article contributes to a reconceptualization of PCK through exploring what is entailed in teachers' understanding of content within the framework of the institutional curriculum, with a central concern for the development of human powers (capacities or abilities, ways of thinking, understanding worlds). In this regard, the reconceptualization is geared toward a vision of teaching - particularly exemplified in the German Didaktik tradition - that construes the central purpose of teaching as the cultivation of human powers through interactions with content (von Humboldt, 2000; also see Hopmann, 2007). This vision is rather different from the conception of teaching as the transmission of content or the development of students' more sophisticated understanding of content - a view that tends to be assumed in the PCK literature.

In this article the reconceptualization of PCK is made by way of a curriculum making framework articulated by Walter Doyle and Ian Westbury (two US-based curriculum scholars), and by examining the capabilities approach developed by David Lambert (a UK- 
based teacher educator) and Bildung-centered Didaktik in the German tradition. The curriculum making framework is employed because it allows us to more adequately conceive of the work of a teacher in relation to the institutional curriculum. Lambert's capabilities approach is examined because the approach articulates what a teacher needs to know and be able to do with respect to content in the UK national curriculum as enacted in classroom, with a view toward the development of human capabilities (which can also be termed powers). Bildung-centered Didaktik is discussed because it provides an elaborate theoretical account of the nature of the content in the state curriculum and of what is entailed in a teacher's understanding of the content for Bildung - the formation of self and the cultivation of human powers. The exploration, as will be seen, brings to light the vital place of curriculum thinking - informed by a theory of content - with respect to teachers' understanding of content for teaching.

To begin with, I provide a brief review of the concept of PCK. I next expound the role of the institutional curriculum with respect to teachers' understanding of content by way of the aforementioned curriculum making framework. Afterwards, I move to examine the capabilities approach and Bildung-centered Didaktik to illustrate what is entailed in a teacher's understanding of the content in the institutional curriculum, with a central concern for the development of human powers or capabilities. What follows is a comparison of the way of conceptualizing teachers' understanding of content for teaching in the capabilities approach and Bildung-centered Didaktik with that of Shulman and associates. I conclude by discussing the implications of the argument for reconceiving PCK and for the development of pre-service teachers' content knowledge for teaching.

\section{PCK: background, conceptualization, issues and developments}


The rise of PCK is inextricably connected with the attempt to professionalize teaching in the US in the 1980s. As a response to the growing criticism over the quality of American schooling, teacher educators argued for professionalizing teaching as a means to raise the standards of teachers and teacher education (Bullough, 2001). Underlying their argument is the belief that teaching as a profession, like medicine and law, has a knowledge base - a codifiable aggregation of knowledge, understanding, skills, and dispositions possessed by professional teachers (Shulman, 1986b, 1987; Wilson, Shulman, \& Richert, 1987).

The articulation of the concept, too, has to do with the attempt of Shulman and associates to address the "missing paradigm" in research on teaching and teacher knowledge - the absence of attention to content or subject matter. Within the various research programs on teaching and teacher knowledge under the "presage-product" and "teacher thinking" paradigms in the 1970s and 1980s, the question of how a teacher transforms his or her content knowledge into forms suitable for teaching was never asked or investigated. Yet, a teacher's ability to transform the content he or she possesses for classroom teaching lies at the heart of teachers' specialized content expertise (Shulman, 1986a, 1986b, 1987; Wilson, Shulman, \& Richert, 1987).

The transformation process entails three kinds of content knowledge for teaching, (1) content knowledge, (2) PCK, and (3) curricular knowledge (Shulman, 1986b). Content knowledge refers to "the amount and organization of knowledge per se in the mind of the teacher" (p. 9), including knowledge of the substantive structure (essential concepts, principles, frameworks) and the syntactic structure (modes of inquiry, canons of evidence, ways of proof) of an academic discipline — terms coined by Schwab (1964). This concept implies no fundamental difference between the kind of content knowledge possessed by a teacher and the kind by a scholar in the academic community. ${ }^{1}$ Therefore, related to PCK is

\footnotetext{
${ }^{1}$ According to Shulman (1987),
} 
the belief that deep and sophisticated disciplinary content knowledge is crucial to "good" teaching.

As a special domain of teachers' content knowledge, PCK allows the teacher "to transform the content knowledge he or she possesses into forms that are pedagogically powerful and yet adaptive to the variations in ability and background presented by students" (Shulman, 1987, p. 15). It includes knowledge of pedagogical representations, of students' prior knowledge, learning difficulties and misconceptions, and of instructional strategies that tap on their prior knowledge and address their learning difficulties and misconceptions: for the most regularly taught topics in one's subject area, the most useful forms of representation of those ideas, the most powerful analogues, illustrations, examples, explanations, and demonstrations — in a word, the ways of representing and formulating the subject that make it comprehensible to others... Pedagogical content knowledge also include an understanding of what makes the learning of specific topics easy or difficult: the conceptions and preconceptions that students of different ages and backgrounds bring with them to the learning of those most frequently taught topics and lessons. If those preconceptions are misconceptions, which they so often are, teachers need knowledge of the strategies most likely to be fruitful in organizing the understanding of learners, because those learners are unlikely to appear before them as blank slates. (Shulman, 1986b, pp. 9-10)

The third category, curricular knowledge, involves an understanding of curricular and instructional programs available for teaching a subject at various grade levels, from which a teacher draws "tools" for classroom teaching. This knowledge also involves what Shulman

Teaching is, essentially, a learned profession. A teacher is a member of a scholarly community. He or she must understand the structures of subject matter, the principles of inquiry that help answer two kinds of questions in each field: What are the important ideas and skills in this domain? and How are new ideas added and deficient ones dropped by those in this area? That is, what are the rules and procedures of good scholarship or inquiry? (p. 9) 
(1986a) calls lateral curriculum knowledge and vertical curriculum knowledge. The former relates knowledge of the curriculum being taught to the curriculum that students are learning in other classes. The latter includes "familiarity with the topics and issues that have been and will be taught in the same subject area during the preceding and later years in school, and the materials that embody them" (Shulman, 1986b, p. 10).

In short, content knowledge, PCK, and curricular knowledge constitute three essential components of content knowledge for teaching. Underpinning the idea of PCK is the assumption that a teacher necessarily transforms the content knowledge of an academic discipline he or she possesses into pedagogical forms. Furthermore, according to Shulman and associates, the transformation entails pedagogical reasoning comprising four aspectspreparation, representation, adaptation and tailoring - directed toward the selection and identification of pedagogical forms catered to students of particular backgrounds and characteristics. And, the transformation is informed by the teacher's knowledge of educational purposes, of learners, of the school curriculum, of general pedagogy, and of the school context (Shulman, 1987; Wilson, Shulman, \& Richert, 1987).

However, numerous issues or criticisms have been raised concerning PCK as a special form of content knowledge for teaching (for more discussions, see Depaepe, Verschaffel, \& Kelchtermans, 2013; Hashweh, 2014; Van Driel \& Berry, 2010). Among those issues or criticisms is a concern over the conception of teaching promoted by PCK. With the foregrounding of "the ways of representing and formulating the subject that make it comprehensible to others" (Shulman, 1986b, p. 9), PCK tends to endorse a transmissive view of teaching — the imparting of a body of knowledge and skills from a teacher to students (Meredith, 1993, 1995; also see McEwan \& Bull, 1991). A second issue concerns whether PCK can be separated from cultural values and normative orientations (e.g., Gudmundsdottir, 1990; Tirosh, Tsamir, Levenson, \& Taback, 2011; Van Driel \& Berry, 2012). As 
Gudmundsdottir (1990) argues, it is only in theory that one can set value apart from PCK; in practice these two are inextricably intertwined. Furthermore, according to Tirosh et al (2011), PCK is inevitably normative; what is accepted as the PCK of expert teachers is shaped by “culturally accepted norms." Third, some scholars question whether PCK can be theoretically distinguished from content knowledge (e.g., Bromme, 1995; McEwan \& Bull, 1991; McNamara, 1991; Segall, 2004). Content knowledge, McEwan \& Bull (1991) and Segall (2004) argue, is inherently pedagogical, with built-in pedagogical forms and meanings.

Partly as an attempt to address these issues, scholars have broadened the idea of PCK by incorporating other types of knowledge - together with beliefs and orientations - into this special knowledge domain (e.g., Grossman, 1990; Magnusson, Krajcik, \& Borko, 1999; Mark, 1990). In English teaching, Grossman asserts that PCK involves four knowledge types: (1) knowledge and beliefs about the purposes of teaching the subject, (2) knowledge of students' understanding, (3) curricular knowledge, and (4) knowledge of instructional strategies. In school science, Magnusson, Krajcik and Borko conceptualize PCK as consisting of five components: (1) science teaching orientation, (2) knowledge of curricula, (3) knowledge of learners, (4) knowledge of instructional strategies, and (5) knowledge of assessment.

In school mathematics, Ball and her colleagues have further articulated and refined Shulman's conception of content knowledge for teaching and, in doing so, made some refinement to PCK (Ball, Thames, \& Phelps, 2008; Hill, Ball, \& Schilling, 2008; Hill, Rowan, \& Ball, 2005; Hill, Schilling, \& Ball, 2004). They use the term "mathematical knowledge for teaching" or "content knowledge for teaching mathematics" to encompass both PCK and content knowledge. PCK is elaborated to include three sub-domains: (1) knowledge of content and students, (2) knowledge of content and teaching, and (3) knowledge of content and curriculum. Content knowledge is articulated to comprise three 
sub-categories: (1) common content knowledge, (2) horizon content knowledge, and (3) specialized content knowledge.

Making a distinction between personal practical knowledge and theoretical or formal knowledge, some researchers point out that PCK in Shulman and associates' conceptualization is a form of personal practical knowledge that, developed by teachers, is contextualized and experience-based (e.g., Fenstermacher, 1994; Friedrichsen \& Berry, 2015; Gess-Newsome, 2015). It is argued that PCK, like content knowledge and general pedagogical knowledge, can also be a form of theoretical or formal knowledge that, developed by researchers or experts, is normative and context-independent. Furthermore, a teacher's PCK is a complex construct involving the transformation and integration of several knowledge types — content knowledge, knowledge of learners, general pedagogical knowledge and curricular knowledge.

In this connection, Loughran and his colleagues developed content representations (CoRe) to display the various aspects of science teachers' PCK (Loughran, Berry, \& Mulhall, 2012; Loughran, Mulhall, \& Berry, 2004). As representations of science teachers' understanding of the content of a given topic for teaching students at a particular level, CoRes are established through having teachers address several questions around the big ideas believed to be important for developing a better or deeper understanding of the content. These questions are: (1) What do you intend students to learn about this idea? (2) Why is it important for students to know this? (3) What else might you know about this idea that you don't intend students to know yet? (4) What difficulties or limitations are connected with teaching this idea? (5) What do you know about student thinking about this idea? (6) What are other factors that influence your teaching of this idea? (7) What instructional strategies will you use and why? (8) How will you ascertain students' understanding or confusion around this idea? With this set of questions, Loughran and his colleagues alluded to a kind of 
curriculum thinking (enabled by Questions 1,2, and 3) that provides a necessary basis for pedagogical reasoning centering around ascertaining students' learning difficulties and selecting effective pedagogical forms - key ingredients of PCK (Questions 4, 5 6, 7, and 8). Their work is informed by a model of teaching for understanding that aims at developing students' better or more sophisticated understanding of science concepts by making learning meaningful and relevant to students and by engaging them in constructing and reconstructing their own knowledge (Loughran, Berry, \& Mulhall, 2012).

The necessity of curriculum thinking in relation to pedagogical reasoning is also highlighted by Gudmundsdottir, Reinertsen and Nordtømme (2000) who employed Klafki's Didaktik model to analyze the nature of PCK of a Norwegian teacher in teaching a topic in the high school history curriculum. The model comprises five questions - in terms of (1) exemplary value, (2) contemporary meaning, (3) future meaning, (4) content structure, and (5) pedagogical representations - that a teacher should ask during lesson planning to explore the educational potential of content and its actualization (for these five questions, see Section 5). It is observed that Shulman's conceptualization of PCK focuses primarily on matters pertaining to questions 4 and 5 - rather than on matters pertaining to questions 1,2 , and 3 which necessitate a special kind of curriculum thinking concerning the educational meaning and significance of content. However, Gudmundsdottir, Reinertsen and Nordtømme did not invoke the concept of Bildung and its related theory of educational content (to be introduced in Section 5) which underpin Klafki's model in their discussion of PCK. After all, Klafki's five questions, not Bildung-centered Didaktik which undergirds the five questions, were employed as a research instrument for analyzing the PCK of a teacher.

From the perspective of Bildung, the central purpose of teaching is the formation of individuality and the cultivation of capabilities or powers - rather than merely the transmission of content or the development of a better or more sophisticated understanding of 
content as held by Loughran and his colleagues. Content is a powerful resource or vehicle for that formation and cultivation - rather than something to be transmitted to, or constructed and reconstructed by, students (see Hopmann, 2007; Lüth, 2000). Through exploring Bildung-centered Didaktik, this article seeks to articulate a kind of curriculum thinking centrally concerned with the development of human powers or capabilities. As such, it can be seen as being related to, but getting beyond, the work of Gudmundsdottir and her colleagues and of Loughran and his colleagues.

Furthermore, this article tackles two other issues in the literature that have not received sufficient attention, despite the criticisms and developments mentioned above. First, in general, there is a lack of concern for the role of the institutional curriculum-in the form of state or nation curriculum guidelines, syllabi, and frameworks - in shaping and determining teachers' knowledge of content. Following Shulman and associates, researchers seem to have taken for granted that the content of an academic discipline possessed by a teacher provides an essential starting point for the transformation of content for teaching in classroom. It is important to note that PCK is a construct developed in the US in the mid-1980s, where a national or state (institutional) curriculum did not exist, where state-developed curriculum frameworks and guidelines had no formal authority over the work of teachers (Cohen \& Spillane, 1992). However, in countries like France, Germany, and Singapore with a national or state curriculum, curriculum guidelines, syllabi and frameworks are authoritative documents issued by national or state ministries or departments of education. As such, these curriculum documents or materials are not just "tools" to be used by teachers as conceived by Shulman and associates. As embodiments of the institutional curriculum, these documents outline what content should be taught, why it should be taught and, to some extent, how teaching should be conducted (Westbury et al., 2016). In such a context, teachers are expected to work with such documents, interpreting and translating the content in the 
institutional curriculum when teaching a particular topic to students of particular backgrounds and experiences. ${ }^{2}$

The second issue, closely related to the first, concerns the lack of research on the nature of teachers' understanding of the content of a school subject in the institutional curriculum (for exceptions, see Deng, 2007a; Deng, 2009; Deng \& Luke, 2008). As mentioned earlier, this content results from an institutional process of selection, organization and transformation of content (a body of knowledge, skills and values) for social, cultural, educational and pedagogical purposes - a process pertaining to the formation of a school subject within the framework of the institutional curriculum (see Deng, 2009; Deng \& Luke, 2008). However, this institutional process of content selection, organization, and transformation has not been accounted for by Shulman and associates in their conceptualization of content knowledge for teaching nor by researchers who adhere to their conceptualization (see Bromme, 1995; Deng, 2007b; Kansanen, 2009). After all, in their conceptualization, transforming the content of an academic discipline into the content of a school subject is construed as a pedagogical task undertaken by an individual teacher (Deng, 2007b). A teacher is to see the content "as a discipline with its own rules and demands" (Doyle, 1992b, p. 499) - rather than as a school subject within the framework of the institutional curriculum. Yet, their assumption about the centrality of an academic discipline has been called into question by scholars who clarify the distinction between school subjects and academic disciplines and argue for the vital role of a school subject in determining and shaping teachers' understanding of content (e.g., Deng, 2007a, 2012; Deng \& Luke, 2008; Stengel, 1997).

\footnotetext{
${ }^{2}$ Interestingly, as result of the curriculum standards movement - epitomized in the No Child Left Behind and Race to the Top acts - over the last two decades, now even the US has a de facto national curriculum in the form of academic standards, outcomes, and prescribed content. Teachers have been increasingly required to plan and conduct their lessons according those standards and outcomes so as to prepare students for high-stakes tests (see Au, 2011; Hopmann, 2008).
} 
What is the role of the institutional curriculum in relation to teachers' professional knowledge of content for teaching? What is entailed in a teacher's understanding of the content in the institutional curriculum for classroom teaching with a central concern for the development of human powers?

\section{The institutional curriculum and teachers' understanding of content for teaching}

The place of the institutional curriculum in relation to teachers' professional understanding of content can be expounded by way of a curriculum making framework articulated by Doyle and Westbury from the perspective of schooling as an institution. Curriculum making, broadly construed, operates across three types of context, the policy (educational policies and discourse), the programmatic (programs, school subjects, school types, streams or tracks), and the classroom (teacher-student interactions, classroom activities, instructional events), yielding three distinct kinds of curriculum (see Deng [2017] for a more detailed discussion).

The policy curriculum, embodied in educational policies and discourse, defines the relation between schooling and both society and culture. It frames what should be going on in a school system in terms of broad purposes or goals and general approaches to teaching and learning (Doyle, 1992a, 1992b). The programmatic curriculum, embodied in curricular structures, programs, and school subjects for a school system (including school types or tracks), translates the purposes and expectations in the policy curriculum into programmatic forms.

The policy and programmatic curricula together constitute the institutional curriculum - in the form of curriculum guidelines, syllabi, and related instructional materials provided to a school system - that gives meaning to, and seeks to direct and support, the practice of teaching in classroom (see Westbury, 2008). As an organizing and operational unit of the institutional curriculum, a school subject constitutes the "locus" of classroom 
teaching (Grossman \& Stodolsky, 1995). The process of constructing a school subject entails a selection and organization of content in view of the goals and expectations in the policy curriculum and a transformation of that content for classroom use (Doyle, 1992a, 1992b; Westbury, 2000). On this account, a school subject embodies a "theory of content"concerning what the content is, how the content is selected, organized, and transformed, and what educational value and significance that the content has for students (as future citizens) within wider social and cultural orders (Doyle, 1992a; also see Deng, 2009, 2011).

The institutional curriculum depends, for its effect, on teachers' enactment in terms of curriculum making in classroom. A teacher is a "curriculum maker" in the sense that he or she translates the institutional curriculum into the classroom curriculum — characterized by a cluster of events or tasks jointly developed by a teacher and a group of students within a particular classroom (Doyle, 1992a, 1992b). The translation requires a further elaboration of the content of a school subject within the framework of the institutional curriculum, making it connect with the experience, interest, and capacity of students (Westbury, 2000).

Therefore, viewed from the perspective of schooling as an institution, the institutional curriculum needs to be employed as an essential frame of reference for conceptualizing what a teacher needs to know and be able to do with regard to content. A teacher necessarily interprets and translates the content of a school subject in the institutional curriculum into instructional events and tasks with reference to both its institutional goals and its theory of content, and in light of students' existing knowledge and experience. This interpretation, as will be argued, gives educational potential to the content in the institutional curriculum. I now turn to examine Lambert's capabilities approach.

\section{The capabilities approach}


Of various approaches to capability development (for a review, see Hart, 2012), the one examined in this article is developed by David Lambert in his attempt to articulate what it means to engage with the revised national (geography) curriculum introduced in 2014 (see Lambert, 2014a, 2014b; Lambert \& Hopkin, 2014; Lambert, Solem \& Tani, 2015). In the UK the national curriculum was first introduced in 1988 and subsequently revised in 2008 and in 2014. Unlike the 2008 version that promotes generic skill-based learning, the recently modified national curriculum emphasizes subject-based learning through providing an explicit framing of what counts as essential knowledge for teaching in various school subjects (Lambert \& Biddulph, 2015). In contrast to the 1988 version that prescribes content in great detail, the new national curriculum only presents a "short and rather spare" curriculum framework comprised by traditional school subjects (Lambert \& Hopkin, 2014). After all, the newly revised national curriculum can be seen a restoration of "a core of essential knowledge" based on school subjects (Department of Education [DfE], 2010) — a direct response to the concern that the promotion of teaching generic skills leads to undermining "disciplinary rigor" in the school curriculum.

Lambert's capabilities approach is informed by the theory of human development developed by Amartya Sen and Martha Nussbaum, according to which the central aim of education is human development and flourishing through the expansion of human capabilities. Capabilities (which can also be called powers) denotes what people can actually be and do, including "the different combinations of human functionings that can be achieved by people, groups, or both" (Lambert, Solem, \& Tani, 2015, p. 724). Moreover, the development of human capabilities is seen as inextricably connected with what Bernstein calls the "pedagogic rights" of young people to individual enhancement, social inclusion and political participation (Lambert, 2014b; Lambert, Solem \& Tani, 2015) 
Furthermore, Lambert bases the capabilities approach on Michael Young's theory of powerful knowledge grounded in social realism (see Young, 2008; Young \& Muller, 2013). According to that theory, disciplinary knowledge, albeit socially constructed and reflecting human special interest and standpoints, has an "objective" conceptual structure with properties and powers of its own (cf. Young, 2008; Young \& Muller, 2013; Wheelahan, 2012). Often theoretical, abstract, and specialized, disciplinary knowledge is powerful knowledge because the acquisition of this knowledge equips students with powers to think beyond their everyday experience, to think the "not yet thought," to envisage alternatives, and to participate in social and political debates (Young \& Muller, 2013). By this account, the development of human capabilities entails "initiating" individual students into various forms and fields of specialized knowledge represented by academic disciplines particularly in sciences, arts and humanities. Without the acquisition of specialized, disciplinary knowledge, students "are deprived and restricted in their personal and intellectual growth into fully capable adults" (Lambert, 2014b, p. 13).

With such theoretical underpinnings, Lambert discussed what it means to engage with the newly revised national curriculum, with a central concern for the development of human capabilities through the teaching of geography. He made a distinction between the national (institutional) curriculum and the classroom/school curriculum and, in doing so, argued for the importance of teachers' interpretation of the national curriculum:

Even so, the formalized curriculum, especially when it is as brief as in the case of England, is a statement of intent or a set of guidelines only. It offers no guarantees over what is actually taught and learned in schools. This is why it is important to distinguish between a National Curriculum and the curriculum of individual schools... The geography curriculum as it is implemented by teachers and experienced by students is always open to interpretation which is why we do need 
specialist trained teachers - teachers who are able to interpret the official intentions laid down in statute through the lens of their specialist knowledge, for it is this that provides the subject curriculum with its educational potential. (Lambert, 2014a, p. 167)

In this connection, the teacher is viewed as a curriculum maker who interprets the national curriculum to create "educational encounters" with powerful disciplinary knowledgeencounters that can take students beyond their everyday experience and equip them with capabilities (Lambert, 2014a, 2014b; Lambert, Solem \& Tani, 2015).

The interpretation of the national curriculum calls for a particular kind of curriculum thinking centering on the "what" and "why" questions around teaching. Using the national curriculum as a guide, the teacher is to ask what constitutes powerful knowledge in the form of ideas, concepts, methods, or procedures. Furthermore, the teacher needs to address why the powerful knowledge is worth teaching, ascertaining its potential in terms of the powers or capabilities this knowledge would give to students who possess it. Among those powers are new ways of understanding the world, powerful ways to analyze geographic phenomena, abilities to imagine alternative futures, and to participate in debates on national and global issues (Lambert, Solem \& Tani, 2015; also see Lambert, 2014a, 2014b;). The teacher, too, needs to engage with the "who" question, understanding what "naïve knowledge" and "everyday experiences" students bring to a classroom—-knowledge and experiences that can be meaningful resources for helping them to acquire powerful disciplinary knowledge (Lambert, Solem \& Tani, 2015). The teacher also needs to grapple with the "how" question, identifying "powerful pedagogies" that ensure the realization of meaningful educational encounters with powerful knowledge in classroom (cf. Roberts, 2013).

Such curriculum thinking needs to be undertaken before the teacher starts to think about how to represent and structure a topic in the national curriculum (Lambert, 2014a). It needs to 
be informed by a teacher's understanding of the central purpose of school geography construed as developing human capabilities. Furthermore, it needs to be enabled by specialist curriculum knowledge - i.e., knowledge of a theory of content as represented by Young's theory of powerful knowledge - that can inform the teacher' thinking about what should be taught in view of that central purpose (see Mitchell \& Lambert, 2015).

However, it is important to note that the kind of curriculum thinking espoused in the capabilities approach is "framed by an overarching context of the discipline of geography" (Mitchell \& Lambert, 2015, pp. 375-376). Mitchell \& Lambert explained:

The subject discipline provides a resource which informs the teacher's curriculum thinking; in this sense it gives the teacher particular identity. The discipline is distinct from the smaller subset of school geography. The discipline provides concepts or "big ideas" (such as place, scale and environment) from which teachers draw. This informs them how to organize the contents of the syllabus - not just how to deliver..., but how to engage students into thinking geographically.... It gives teachers choices over how they think about pupils' needs and pedagogy. (p. 376)

In short, disciplinary knowledge is essential for the teacher to engage in curriculum thinking when interpreting and enacting the UK national curriculum in classroom (Lambert, Solem, \&Tani, 2015). Therefore, like Shulman and associates, Lambert believes that the teacher needs to have substantive and syntactic knowledge of an academic discipline concerning the school subject to be taught (Mitchell \& Lambert, 2014). This is important because the academic discipline needs to be employed as a resource for "nurturing and developing in children the capacity to "think geographically"' (Lambert \& Hopkin, 2014, p. 73).

Nevertheless, this foregrounding of an academic discipline in curriculum thinking entails bypassing the purpose and related theory of content (if any) embedded in the institutional curriculum. In the words of Doyle (1992b), it in effect allows a teacher to "lift 
the [institutional] curriculum away from texts and materials to give it independent existence" (p. 499). After all, the kind of curriculum thinking espoused by Lambert is, as already mentioned, informed by Sen's and Nussbaum's theory of human development and Young's theory of powerful knowledge. As such, it champions a "possibilist" interpretation of the national curriculum that "could be different from that which the government may have intended" (Lambert \& Hopkin, 2014, p. 64). It is also important to note that Young's theory of powerful knowledge is not particularly formulated for the purpose of developing general human powers or capabilities stressed by Sen and Nussbaum. It only purports that the acquisition of powerful disciplinary knowledge entails the development of intellectual powers or capabilities that are distinctive and largely disciplines-based (e.g., scientific, historical, geographical, artistic). As such, the theory itself does not tells us much about what potential content has for developing general human powers or capabilities and how that potential can be disclosed in classroom.

As argued earlier, from the perspective of schooling as an institution, a teacher is expected to interpret and transform the content of a school subject with reference to the purposes and theory of content embedded in the institutional curriculum. In a context where the institutional curriculum is developed with a central concern for the cultivation of human powers and undergirded by a related theory of content, how should the nature of the content in the institutional curriculum be properly conceived or conceptualized? What might constitute a theory of content particularly formulated for the cultivation of general human powers or capabilities by way of the institutional curriculum planning and classroom enactment? How should a teacher ascertain the educational potential of content in the institutional curriculum for the cultivation? To address these questions, I now turn to Bildung-centered Didaktik. 


\section{Bildung-centered Didaktik}

As "the oldest and most important trend within the modern Didaktik tradition"

(Gudmudsdottir, Reinertsen, \& Nordtømme, 2000, pp. 320-321), Bildung-centered Didaktik has its origin in the thinking of Wolfgang Ratke, Johan Amos Comenius and Johann Friedrich Herbart in the seventeenth and eighteen centuries. The development of Bildungcentered Didaktik was also deeply influenced by human-science educational theory (geisteswissenschaftliche Bildungstheorie) that emerged in the early $20^{\text {th }}$ century. The spread of Didaktik in Germany too has to do with the need for state curriculum planning - in terms of developing curriculum guidelines, the Lehrplan, for the school system and teacher education seminaries within a German state (Hopmann, 2007; Hopmann \& Riquarts, 2000).

Bildung-centred Didaktik, then, has to be concerned with the enactment of the state curriculum in classroom in view of Bildung. Bildung refers to the process and outcomes of self-formation, encompassing the cultivation of intellectual and moral powers, the developments of dispositions such as sensibility, self-awareness, liberty and freedom, and dignity (Hopmann, 2007; von Humboldt, 2000). Later, the concept is revised to include the development of the dispositions of self-determination (autonomy), co-determination (participation), and solidarity with a view to prepare students to take responsibility in society (Klafki 1998). To attain Bildung, the individual seeks to "grasp as much [of the] world as possible" and to make contribution to mankind through cultivating his or her unique self, intellectual and moral powers (von Humboldt, 2000). The world, independent of human thinking, is processed by human thought—represented by academic disciplines (humanities and sciences) — and general action (Lüth, 2000). The role of academic knowledge in Bildung is conceived as:

- a means of expressing, exercising and intuiting powers; 
- a potential stimulus for human development;

- a counterpart to mark out the boundaries of the individual; and

- a means of objectivizing ideas and powers in order to leave traces in the world ( $\mathrm{p}$. 77).

As such, academic knowledge is "used in the service of intellectual and moral Bildung" ( $p$. 77), and academic disciplines are an indispensable resource/vehicle for Bildung.

Underpinning Bildung-centred Didaktik is a well-articulated theory of educational content (Theorie der Bildungsinhalte) that seeks to inform curriculum planning and classroom practice directed toward Bildung. Central to that theory are four related concepts, contents of education (Bildungsinha), educational substance (Bildungsgehalt), the elementary (das Elementare) and the fundamental (das Fundamentale). The contents embodied in the state curriculum is characteristically called by curriculum designers "contents of education" - the result from a deliberative process of selection and organization of the wealth of the academic knowledge, experience and wisdom for Bildung. Such contents, set aside for classroom teaching, embody educational potential for Bildung:

Curriculum designers assume that these contents, once the children or adolescents have internalized and thus acquired them, will enable the young people to "produce a certain order" (Litt) in themselves and at the same time in their relation to the world, to "assume responsibility" (Weniger), and to cope with the requirements of life. The contents of teaching and learning will represent such order, or possibilities for such order, such responsibilities, inevitable requirements and opportunities...(Klafki, 2000, p. 150).

The educational potential of content is determined by educational substance comprised by elementary elements (concepts, principles, values, methods) that can bring about Bildung-a fundamental change in the perspectives, modes of thinking, dispositions, and ways of being- 
in-the-world of individuals (Krüger, 2008). Those elementary elements, alongside their educational meaning and significance, are to be identified and interpreted by the teacher in classroom.

Informed by this theory of content, the state curriculum framework only lays out school subjects and their contents to be covered in school, but does not specify educational substance, meaning, and significance (Hopmann, 2007). In classroom teachers are entrusted with a high level of professional autonomy to interpret the state curriculum framework. They are viewed as curriculum makers "working within, but not directed by" the state curriculum framework, informed by the idea of Bildung and the didaktik way of thinking (Westbury, 2000, p. 26).

Curriculum making in classroom is enabled by lesson planning aiming to design opportunities for students to make "fruitful encounters" with the content. The teacher starts with understanding the content contained in the state curriculum-i.e., the content of education. He or she is supposed to "re-enact the pedagogical decision made by the curriculum designers and embedded in the curriculum contents" and "reflect which considerations must have led to the inclusion of a particular item or a particular basic issue" as a possible content of education (Klafki, 2000, p. 144). Furthermore, lesson planning entails a kind of curriculum thinking named Didaktik thinking (paralleling to the kind in the capabilities approach) - centering on the what and why of teaching - informed by the above theory of content and directed toward Bildung. The teacher is to identify the elementary elements that constitute the educational substance of a particular content, with particular students in mind and within a particular historical context—present and future (Klafki, 2000). Furthermore, the teacher is to ascertain the educational potential of content through analyzing and unpacking the educational meaning and significance of the elementary elements from the perspective of Bildung. 
In his 1958 classic "Didaktik analysis as the core of preparation of instruction"virtually read by every teacher in Germany_-Klafki (2000) provided a model of instructional planning based on the above theory of content and directed toward Bildung. He formulated a five-step set of questions that serves to facilitate teachers' didaktik thinking during instructional planning, directed toward identifying the educational substance and exploring the educational potential of content and its realization:

1. What wider or general sense or reality does this content exemplify and open up to the learner? What basic phenomenon or fundamental principle, what law, criterion, problem, method, technique, or attitude can be grasped by dealing with this content as an "example"?

2. What significance does the content in question, or the experience, knowledge, ability, or skill, to be acquired through this topic, already possess in the minds of the children in my class? What significance should it have from a pedagogical point of view?

3. What constitutes the topic's significance for the children's future?

4. How is the content structured (which has been placed in a specifically pedagogical perspective by questions 1,2 , and 3)?

5. What are the special cases, phenomena, situations, experiments, persons, elements of aesthetic experience, and so forth, in terms of which the structure of the content in question can become interesting, stimulating, approachable, conceivable, or vivid for children of the stage of development of this class? (pp. 151-157)

Questions 1, 2, and 3 concern the educational substance and potential of content - in terms of what should be taught, what the content signifies, and why it is significant for students. These questions go beyond a teacher's understanding or comprehension of the content in terms of big ideas, concepts, and methods. They speak of "the ways in which a teacher makes connections with the deepest objective substance of the cultural asset" 
(Vâsquez-levy, 2002, p.122) and unlocks its potential for human formation and flourishing. Questions 4 and 5 deal with the means of teaching the content and actualizing its educational potential - in terms of content structure and pedagogical representations. As with the above capabilities approach, addressing the what and why questions is prior to, and a precondition for, addressing the how question. In Didaktik the search for methods (the how) is the final step - the "crowning" moment in lesson planning (Klafki, 2000).

\section{Conceptualizing teachers' understanding of content for teaching: comparison and contrast}

There are significant parallels between the capabilities approach and Bildung-centered Didaktik with respect to conceptualizing teachers' understanding of content for teaching. In both theories the central purpose of classroom teaching is seen as developing human capabilities or powers. The institutional curriculum — in terms of curriculum guidelines - is held as an essential starting point for curriculum making in classroom, with a teacher interpreting the content in the curriculum to create educational "encounters" with the essence of that content for students. The interpretation entails curriculum thinking — centering on the what and why of teaching - directed toward determining the "essence" of content comprised by powerful, elementary elements - and ascertaining its educational potential for developing capabilities or powers.

There are, of course, important differences. The capabilities approach stresses the development of discipline (geography)-based capabilities - also called geo-capabilities - for the promotion of "human potential and well-being both as individuals and as members of a society" (Lambert, Solem, \&Tani, 2015, p. 724). Bildung-centered Didaktik, on the other hand, emphasizes the cultivation of general human powers for the formation of autonomous, independent, participatory, and responsible human beings. In the former, the development of 
human capabilities is achieved through an "initiation" into the powerful disciplinary knowledge in school geography (see Lambert \& Hopkin, 2014; Lambert, Solem, \&Tani, 2015). In the latter, by contrast, the cultivation of human powers is through the 'fruitful meetings' of students with content in a way that content is made to open up manifold opportunities for the cultivation (Hopmann, 2007; Klafki, 2000). Furthermore, in the former, a teacher's ascertaining of the educational potential of content is informed by a theory of content - i.e., Young's theory of powerful knowledge - that might be different from the theory of content embedded in the institutional curriculum. In the latter, by contrast, a teacher's analysis of educational potential is informed by a theory of content that also undergirds the institutional curriculum.

Differences aside, both the capabilities approach and Bildung-centered Didaktik contrast sharply with Shulman and associates with respect to conceptualizing teachers' understanding of content for teaching. For Shulman and associates, the central purpose of teaching is the transmission or imparting of disciplinary knowledge to students. The content of an academic discipline possessed by a teacher - rather than the content in the institutional curriculum - provides an essential point of departure for instructional planning, with the teacher transforming his or her disciplinary content into pedagogical forms. The transformation calls for pedagogical reasoning - centering on the how of teaching - geared toward the search for effective ways of representing and reformulating content that makes it comprehensible for students.

Behind these differences are two distinctive ways of theorizing teachers' content understanding. In both the capabilities approach and Bildung-centered Didaktik, theorizing teachers' understanding of content is largely a normative and institutionally-oriented undertaking, focusing on what teachers should understand the content, that is, on the formal, theoretical knowledge for teaching. It is normative because the theorizing is normatively 
informed by a conception of education as the development of human powers or capabilities. It is institutionally-oriented because the theorizing conceives the work of a teacher as embedded in the institutional context of schooling and proceeds from the practical requirement of a teacher to interpret and enact the institutional curriculum in classroom. After all, what the capabilities approach or Bildung-centered Didaktik provides is a "knowledge base" articulated by teacher educators to inform preservice teacher education and continuous professional development, with a concern for enacting the institutional curriculum and for developing human powers or capabilities.

By contrast, the way of theorizing employed by Shulman and associates is largely descriptive and empirical research-oriented, with a focus on what teaches understand the content - that is, on the personal practical knowledge of teachers. It is not directed toward any explicit normative conception of education, nor is it concerned with how the institutional curriculum should regulate and frame the wok of teachers. It too does not address the need of a teacher to work with the institutional curriculum in classroom. What this way of theorizing renders are largely research models that seek to guide and advance further inquiry into teacher characteristics and teaching practice, whereas such models are also applicable for designing programs for teacher education and professional development (Kansanen, 1995).

\section{Discussion and Conclusion}

The article contributes to a re-conceptualization of PCK through an exploration of what is entailed in teachers' understanding of content within the framework of the institutional curriculum, with a central concern for the development of human powers or capabilities. By way of a curriculum making framework and in light of Lambert's capabilities approach and Bildung-centered Didaktik, I argue that a teacher necessarily interprets the content in the 
institutional curriculum, identifying its powerful, elementary elements and ascertaining its educational potential for developing human powers or capabilities. The interpretation calls for a special kind of curriculum thinking - centering on the what and why of teaching which is informed by a theory of content concerning what content is, what educational potential content has, and how content can be made to open up opportunities for cultivating human powers.

This curriculum thinking - directed toward identifying the powerful, elementary elements and ascertaining the educational potential of content - needs to be seen as being at the heart of teachers' professional understanding of content. It provides an essential basis for pedagogical reasoning concerned with the identification and selection of pedagogical forms (representations, instructional strategies, activities) - an essential component of PCK. Those powerful, elementary elements (basic ideas, concepts, themes, methods) can be seen as constituting another important component of PCK on two grounds. First, as indicated in the preceding discussion, those elements are inherently pedagogical, an understanding of which allows a teacher to penetrate into the "essence" of content and to help students grasp the content and develop intellectual and moral powers through encounters with the essence. In the words of Shulman (1986b), the elements embody "the aspects of content most germane to its teachability" (p. 9). Second, identified by a teacher through interpreting the institutional curriculum in a particular classroom context, those basic elements stand for a special kind of personal practical (content) knowledge which can set a teacher apart from a non-teaching subject matter expert (for a more detailed discussion, see Deng, 2001, 2007a).

Furthermore, a theory of content - that seeks to inform curriculum thinking in classroom - constitutes specialist curriculum knowledge for classroom teachers - a form of theoretical or formal knowledge developed by curriculum developers, researchers or theorists. This theory of content can also be a form of personal practical knowledge 
developed by teachers as a result of their interactions with the institutional curriculum, shaped by their teaching experience and professional development. Teachers need such specialist curriculum knowledge if they are to be integral to the institutional curriculum as enacted in classroom.

To argue for the place of curriculum thinking, alongside a theory of content, in teachers' professional understanding of content is particularly timely and pertinent in view of the current global movement toward academic standards, outcomes and accountability. The "curriculum" literally disappears in educational policy and discourse concerning the purposes of teaching, teachers and teaching, particularly evident in the US. As schools are held accountable for delivering academic standards and outcomes, the central purpose of teaching becomes promoting students' academic achievement measured by standardized tests. And a teacher is seen as an educational technocrat who employs so-called best practices or prescribed methods that can get students to meet the academic standards (Hopmann, 2008; also see $\mathrm{Au}, 2001)$. Through bringing curriculum thinking into the conversation on teachers' content knowledge, this article serves to remind us of an essential purpose of school education - the development of human powers or capabilities. This purpose, as noted earlier, is vital for human development and flourishing. This is a social justice issue as well since the development is an entitlement for all young people, regardless of their socioeconomic status, races, and genders (cf. Lambert, 2014b). To achieve this essential purpose requires teachers to be curriculum makers who identify the powerful or elementary elements of content and interpret its educational potential. This identification and interpretation, in turn, calls for curriculum thinking, alongside specialist curriculum knowledge, that goes far beyond the employment of best practices or prescribed methods espoused in the standards and accountability movement. 
If the argument of this article is taken seriously, then the development of pre-service teachers' content knowledge needs to be placed within the context of interpreting and enacting the institutional curriculum for teaching, with a central concern for the development of human powers or capabilities needed for today and tomorrow. Preservice teachers need to learn how to interpret and transform the content in the curriculum into instructional activities and events in view of this central purpose. They need to be provided with opportunities to engage in curriculum thinking, learning how to identify the powerful or elementary elements of content and ascertain its educational potential. For this, they need to develop a wellinformed understanding of this central purpose of schooling and acquire a theory (or theories) of content that can inform their curriculum thinking. These requirements, I believe, also apply to the professional development of in-service teachers' understanding of content for teaching, with different emphases and levels of sophistication.

To be clear, to foreground teachers' understanding of content within the framework of the institutional curriculum is not to imply that teachers only need to know the content taught in school. Academic disciplines are an indispensable resource/vehicle for the development of human powers or capabilities and dispositions. Disciplinary knowledge allows a teacher to engage in deep thinking about curriculum questions of what to teach and why with regard to the needs and experiential knowledge of students (Lambert \& Biddulph, 2015). It enables teachers to make "connections with the deepest objective substance of the cultural asset" (Vásquez-Levy, 2002, p. 122) and to unlock the rich potential of content for Bildung. Therefore, teachers' understanding of the content in the curriculum must be enriched and broadened by knowledge of related academic disciplines - including both the substantive and syntactic aspects.

Nevertheless, the task of developing teachers' knowledge of content for teaching within the context of the institutional curriculum, with a central concern for developing human 
powers, would not be effective without being informed by both empirical research and theory development. We do not have a theory (or theories) of content that can inform curriculum planning and classroom teaching directed toward the development of human powers deemed important today. Empirically, we know very little about what is entailed in teachers' understanding of content when interpreting and enacting the institutional curriculum in classroom. What are the intellectual, moral, social, civic, and technological powers or capabilities an educated person needs to possess in the today's and tomorrow's context? What are the types of knowledge - disciplinary, experiential, cultural, practical, etc. - that could contribute to the cultivation of human powers for all students? How would those various kinds of knowledge be selected, organized and transformed into the content of the institutional curriculum in a way that supports curriculum making in classroom directed toward that cultivation? What do teachers need to know and be able to do with respect to the content of the curriculum when teaching a particular topic for students of particular backgrounds, interests and experiences, for the purpose of developing powers or capabilities? Neither Bildung-centered Didaktik nor the capabilities approach provides direct answers to these questions. Such questions cry out for theoretically-informed and thoughtful empirical research and inquiry. They too call for normative and institutional context-dependent theorizing, as exemplified in the German Didaktik tradition, descriptive and research-oriented theory building as represented by Shulman and associates' conceptualization, and their combination as well.

\section{Acknowledgements}

This paper stems from a keynote presentation delivered at the $4^{\text {th }}$ International Conference on Teacher Education, National University of Taiwan, Taipei, Taiwan, October 21-23, 2016. I are very grateful to professors Shihkuan Hsu and Jinn Guey Lay for the invitation. I also want 
to thank Ian Westbury and two anonymous reviewers for their very useful comments on the earlier drafts of the paper.

\section{Disclosure statement}

No potential conflict of interest was reported by the author.

\section{References}

$\mathrm{Au}, \mathrm{W}$. (2011). Teaching under the new Taylorism: High-stakes testing and the standardization of the 21st century curriculum. Journal of Curriculum Studies, 43(1), 25-45. doi: 10.1080/00220272.2010.521261

Ball, D. L., \& Bass, H. (2000). Interweaving content and pedagogy in teaching and learning to teach: Knowing and using mathematics. In J. Boader (Ed.), Multiple perspectives on teaching and learning mathematics (pp. 83-104). Westport, CT: Ablex.

Ball, D. L., Thames, M. H., \& Phelps, G. (2008). Content knowledge for teaching: what makes it special? Journal of Teacher Education, 59, 389-407. doi: $10.1177 / 0022487108324554$

Blömeke, S., Felbrich, A., Müller, C., Kaiser, G., \& Lehmann, R. (2008). Effectiveness of teacher education. ZDM Mathematics Education, 40, 719-734. doi: 10.1007/s11858-0080096-x

Bromme, R. (1995). What exactly is pedagogical content knowledge? Critical remarks regarding a fruitful research program. In S. Hopmann \& K. Riquarts (Eds.), Didaktik and/or curriculum (pp. 205-216). Kiel: Institut für die Pädagogik der Naturwissenschaften an der Universität Kiel.

Bullough, R. V. (2001). Pedagogical content knowledge circa 1907 and 1987: A study in the history of an idea. Teaching and Teacher Education, 17, 655-666. doi: 10.1016/S0742051X(01)00022-1

Clermont, C. P., Krajcik, J. S., \& Borko, H. (1993). The influence of an intensive in-service workshop on pedagogical content knowledge growth among novice chemical demonstrators. Journal of Research on Science Teaching, 30(1), 21-43. doi: 10.1002/tea.3660300104

Cohen, D. K. and Spillane, J. P. (1992). Policy and practice: The relations between governance and instruction. In Grant, C. (Ed.), Review of research in education, vol. 18 (pp 3-49). Washington, DC: American Educational Research Association.

Deng, Z. (2001). The distinction between key ideas in teaching school physics and key ideas in the discipline of physics. Science Education, 85, 263-278. doi: 10.1002/tea.3660300104 
Deng, Z. (2007a). Knowing the subject matter of a secondary-school science subject. Journal of Curriculum Studies, 39, 503-535. doi: 10.1080/00220270701305362

Deng, Z. (2007b). Transforming the subject matter: examining the intellectual roots of pedagogical content knowledge. Curriculum Inquiry, 37, 279-295. doi: 10.1111/j.1467873X.2007.00386.x

Deng, Z. (2009). The formation of a school subject and the nature of curriculum content: An analysis of liberal studies in Hong Kong. Journal of Curriculum Studies, 41, 585-604. doi: $10.1080 / 00220270902767311$

Deng, Z. (2012). School subjects and academic disciplines: the differences. In A. Luke, K. Weir, A. Woods, \& M. Moroney (Eds.), Curriculum, syllabus design and equity: A primer and model (pp.40-73). New York, NY: Routledge.

Deng, Z. (2017). Rethinking curriculum and teaching. In G. W. Noblit (Ed.), Oxford Research Encyclopaedia of Education (pp. 1-25). New York, NY: Oxford University Press

Deng, Z., \& Luke, A. (2007). Subject matter: Defining and theorizing school subjects. In F. M. Connelly, M. F. He, \& J. Phillion (Eds.), Sage handbook of curriculum and instruction (pp. 66-87). Thousand Oaks, CA: Sage.

Depaepe, F., Verschaffel, L., \& Kelchtermans, G. (2013). Pedagogical content knowledge: A systematic review of the way in which the concept has pervaded mathematics educational research. Teaching and Teacher Education, 34 (1), 12-25. doi: 10.1016/j.tate.2013.03.001

Department for Education (DfE). (2010). The importance of teaching. London: HMSO.

Doyle, W. (1992a). Constructing curriculum in the classroom. In F. K. Oser, A. Dick, \& J. Patry (Eds.), Effective and responsible teaching: The new syntheses (pp 66-79). San Francisco, CA: Jossey-Bass.

Doyle, W. (1992b). Curriculum and pedagogy. In P. W. Jackson (Ed.), Handbook of research on curriculum (pp 486-516). New York, NY: Macmillan.

Fenstermacher, G. D. (1994). The knower and the known: The nature of knowledge in research on teaching. Review of Research in Education, 20, 3-56. doi: 10.3102/0091732X020001003

Friedrichsen, P., \& Berry, A. (2015). Science teacher PCK learning progressions: promises and challenges. In A. Berry, P. Friedrichsen, \& J. Loughran (Eds.), Re-examining pedagogical content knowledge in science education (pp. 214-228). New York, NY: Routledge.

Gess-Newsome, J. (2015). A model of teacher professional knowledge and skill including PCK. In A. Berry, P. Friedrichsen, \& J. Loughran (Eds.), Re-examining pedagogical content knowledge in science education (pp. 28-42). New York, NY: Routledge 
Grimmett, P., \& MacKinnon, A. (1992). Craft knowledge and the education of teachers. Review of Research in Education, 18, 385-456. doi: 10.3102/0091732X018001385

Grossman, P. L. (1990). The making of a teacher: Teacher knowledge and teacher education. New York, NY: Teachers College Press.

Grossman, P. L., \& Stodolsky, S. S. (1995). Content as context: the role of school subjects in secondary school teaching. Educational Researcher, 24(8), 5-11, 23. doi: 10.3102/0013189X024008005

Gudmundsdottir, S. (1990). Values in pedagogical content knowledge. Journal of Teacher Education, 41(3), 44-52. doi:10.1177/002248719004100306

Gudmundsdottir, S., Reinertsen, A., \& Nordtømme, N. P. (2000). Klafki's Didaktik analysis as a conceptual framework for research on teaching. In I. Westbury, S. Hopmann, \& K.

Riquarts (Eds.), Teaching as a reflective practice: The German Didaktik tradition (pp. 319334). Mahwah, NJ: Erlbaum.

Haertel, E. H. (1991). New forms of teacher assessment. Review of Research in Education, 17, 3-29. doi: 10.3102/0091732X017001003

Hart, C. S. (2012). The capability approach and education. Cambridge Journal of Education, 42, 275-282. doi: 10.1080/0305764X.2012.706393

Hashweh, M. (2014). Pedagogical Content Knowledge: Lee Shulman. In D. C. Phillips (Ed.), Encyclopedia of educational theory and philosophy. Thousand Oaks, CA: Sage.

Hill, H. C., Ball, D. L., \& Schilling, S. G. (2008). Unpacking pedagogical content knowledge: conceptualizing and measuring teachers' topic-specific knowledge of students. Journal for Research in Mathematics Education, 39, 372-400. Retrieved from http://www.jstor.org/stable/40539304

Hill, H. C., Rowan, R., \& Ball, D. L. (2005). Effects of teachers' mathematical knowledge for teaching on student achievement. American Educational Research Journal, 41, 371-406. doi: $10.3102 / 00028312042002371$

Hill, H., Schilling, S., \& Ball, D. L. (2004). Developing measures of teachers' mathematics knowledge for teaching. The Elementary School Journal, 105 (1), 11-30. doi: $10.1086 / 428763$

Hopmann, S. (2007). Restrained teaching: The common cores of Didaktik. European Educational Research Journal, 6, 109-124. doi: 10.2304/eerj.2007.6.2.109

Hopmann, S. (2008). No child, no school, no state left behind: Schooling in the age of accountability. Journal of Curriculum Studies, 40, 417-456. doi: 10.1080/00220270801989818

Hopmann, S., \& Riquarts (2000). Starting a dialogue: A beginning conversation between Didaktik and the curriculum traditions. In I. Westbury, S. Hopmann, \& K. Riquarts (Eds.), 
Teaching as a reflective practice: The German Didaktik tradition (pp. 3-11). Mahwah, NJ: Erlbaum.

Humboldt, W. V. (2000). Theory of Bildung. In I. Westbury, S. Hopmann, \& K. Riquarts (Eds.), Teaching as a reflective practice: The German Didaktik tradition (pp. 57-61).

Mahwah, NJ: Erlbaum.

Kansanen, P. (1995). The Deutsche Didaktik. Journal of Curriculum Studies, 27, 347-352. doi:10.1080/0022027950270401

Kansanen, P. (2009). Subject-matter didactics as a central knowledge base for teachers, or should it be called pedagogical content knowledge? Pedagogy, Culture \& Society, 17 (1), 2939. doi:10.1080/14681360902742845

Karmon, A. (2007). "Institutional organization of knowledge": The missing link in educational discourse. Teachers College Record, 109, 603-634. Retrieved from http://www.tcrecord.org/library

Klafki, W. (1998). Characteristics of critical constructive Didaktik. In B. B. Gundem \& S. Hopmann (Eds.), Didaktik and/or curriculum: An international dialogue (pp. 307-330). New York, NY: Peter Lang.

Klafki, W. (2000). Didaktik analysis as the core of preparation. In I. Westbury, S. Hopmann, $\&$ K. Riquarts (Eds.), Teaching as a reflective practice: The German Didaktik tradition (pp. 139-159). Mahwah, NJ: Erlbaum.

Krüger, R. A. (2008). The significance of the concepts "elemental" and "fundamental" in didactic theory and practice. Journal of Curriculum Studies, 40, 215-250. doi:

$10.1080 / 00220270701332267$

Lambert, D. (2014a). Curriculum leadership and the knowledge-led school. In M.Young, D. Lambert, C. Roberts, \& M. (Eds.), Knowledge and the future school: Curriculum and social justice (pp. 157-187). London: Bloomsbury Publishing.

Lambert, D. (2014b). Curriculum thinking, 'capabilities' and the place of geographical knowledge in schools. Syakaika Kenkyu (Journal of Educational Research on Social Studies), 81, 1-11. Retrieved from http://jerass.jp

Lambert, D., \& Biddulph, M. (2015). The dialogic space offered by curriculum-making in the process of learning to teach, and the creation of a progressive knowledge-led curriculum.

Asia-Pacific Journal of Teacher Education, 43, 210-224. doi:

10.1080/1359866X.2014.934197

Lambert, D., \& Hopkin, J. (2014). A possibilist analysis of the geography national curriculum in England. International Research in Geographical and Environmental Education, 23(1), 64-78. doi: 10.1080/10382046.2013.858446

Lambert, D., Solem, M., \& Tani, S. (2015). Achieving human potential through geography education: A capabilities approach to curriculum making in schools. Annals of the Association of American Geographers, 105, 723-735. doi: 10.1080/00045608.2015.1022128 
Lederman, N. G., Gess-Newsome, J., \& Latz, M. S. (1994). The nature and development of pre-service teachers' conception of subject matter and pedagogy. Journal of Research in Science Teaching, 31, 129-146. doi: 10.1002/tea.3660310205

Loughran, J., Berry, A., \& Mulhall, P. (2012). Understanding and developing science teachers' pedagogical content knowledge. New York, NY: Springer.

Loughran, J., Mulhall, P., \& Berry, A. (2004). In search of pedagogical content knowledge in science: Developing ways of articulating and documenting professional practice. Journal of Research in Science Teaching, 41, 370-391. doi: 10.1002/tea.20007

Lüth, C. (2000). On Wilhelm von Humboldt's theory of Bildung. In I. Westbury, S. Hopmann, \& K. Riquarts (Eds.), Teaching as a reflective practice: The German Didaktik tradition (pp. 63-84). Mahwah: Erlbaum

Magnusson, S., Krajcik, J., \& Borko, H. (1999). Nature, sources and development of pedagogical content knowledge. In J. Gess-Newsome \& N. G. Lederman (Eds.), Examining pedagogical content knowledge (pp. 95-132). Dordrecht, the Netherlands: Kluwer.

Marks, R. (1990). Pedagogical content knowledge: From a mathematical case to a modified conception. Journal of Teacher Education, 41(3), 3-11. doi: 10.1177/002248719004100302

McEwan, H., \& Bull, B. (1991). The pedagogic nature of subject matter knowledge. American Educational Research Journal, 28, 316-334. doi: 10.3102/00028312028002316

McNamara, D. (1991). Subject knowledge and its application: problems and possibilities for teacher educators. Journal of Education for Teaching, 17, 113-128. doi: $10.1080 / 0260747910170201$

Meredith, A. (1993). Knowledge for teaching mathematics: some student teachers' views. Journal of Education for Teaching, 19, 325-338. doi: 10.1080/0260747930190308

Meredith, A. (1995). Terry's learning: some limitations of Shulman's pedagogical content knowledge. Cambridge Journal of Education, 25, 175-187. doi: 10.1080/0305764950250205

Mitchell, D., \& Lambert, D. (2015). Subject knowledge and teacher preparation in English secondary schools: the case of geography. Teacher Development, 19, 365-380. doi: $10.1080 / 13664530.2015 .1042024$

Peterson, R. F., \& Treagust, D. F. (1998). Learning to teach primary science through problem-based learning. Science Education, 82, 215-237. doi: 10.1002/(SICI)1098237X(199804)82:2<215::AID-SCE6>3.0.CO;2-H

Phelps, G, \& Schilling, S. (2004). Developing measures of content knowledge for teaching reading. The Elementary School Journal, 105(1), 31-48. doi: 10.1086/428764

Roberts, M. (2013). Geography through enquiry. Sheffield: Geographical Association. 
Schmidt, W. H., Blömeke, S., \& Tatto, M. T. (2011). Teacher education matters. A study of the mathematics teacher preparation from six countries. New York, NY: Teacher College Press.

Schwab, J. J. (1964). The structure of the disciplines: Meaning and significance. In G. W. Ford \& L. Pugno (Eds.), The structure of knowledge and the curriculum (pp. 1-30). Chicago, IL: Rand McNally.

Segall, A. (2004). Revisiting pedagogical content knowledge: the pedagogy of content/the content of pedagogy. Teaching and teacher education, 20, 489-504. doi:

10.1016/j.tate.2004.04.006

Shulman, L. S. (1986a). Paradigms and research programs in the study of teaching: A contemporary perspective. In M. C. Wittrock (Ed.), Handbook of research on teaching (3rd ed., pp. 3-36). New York, NY: Macmillan.

Shulman, L. S. (1986b). Those who understand: Knowledge growth in teaching. Educational Researcher, 15(2), 4-14. doi: 10.3102/0013189X015002004

Shulman, L. S. (1987). Knowledge and teaching: Foundations of the new reform. Harvard Educational Review, 57(1), 1-22. doi: 10.17763/haer.57.1.j463w79r56455411

Stengel, B. S. (1997). "Academic discipline" and "school subject": Contestable curricular concepts. Journal of Curriculum Studies, 29, 585-602. doi: 10.1080/002202797183928

Tirosh, D., Tsamir, P., Levenson, E., \& Tabach, M. (2011). From preschool teachers' professional development to children's knowledge: comparing sets. Journal of Mathematics Teacher Education, 14, 113-131. doi: 10.1007/s10857-011-9172-1

Thornton, S. J., \& Barton, K. C. (2010). Can history stand alone? Drawbacks and blind spots of a "disciplinary" curriculum. Teachers College Record, 112, 2471-2495. Retrieved from http://www.tcrecord.org/library

Van Driel, J. H., \& Berry, A. (2010). The teacher education knowledge base: pedagogical content knowledge. In P. L. Peterson, E. Baker, \& B. McGaw (Eds.), Third international encyclopedia of education (Vol. 7, pp. 656-661). Amsterdam: Elsevier.

Vásquez-Levy, D. (2002). Bildung-centred Didaktik: A framework for examining the educational potential of subject matter. Journal of Curriculum Studies, 34(1), 117-128. doi: $10.1080 / 00220270110056581$

Westbury, I. (2000). Teaching as a reflective practice: What might Didaktik teach curriculum. In I. Westbury, S. Hopmann, \& K. Riquarts (Eds.), Teaching as a reflective practice: The German Didaktik tradition (pp. 15-39). Mahwah, NJ: Erlbaum.

Westbury, I. (2008). Making Curricula: Why Do States Make Curricula, and How? In F. M. Connelly, M. F. He, \& J. Phillion (Eds.), The Sage handbook of curriculum and instruction (pp. 45-65). Thousand Oaks, CA: Sage. 
Westbury, I., Aspfors, J., Fries, A. V., Hansén, S. E., Ohlhaver, F., Rosenmund, M., \& Sivesind, K. (2016). Organizing curriculum change: an introduction. Journal of Curriculum Studies, 48, 729-743. doi: 10.1080/00220272.2016.1186736

Wheelahan, L. (2012). Why knowledge matters in curriculum: A social realist argument. London: Routledge.

Wilson, S. M., Shulman, L. S., \& Richert, A. E. (1987). "150 different ways" of knowing: Representations of knowledge in teaching. In J. Calderhead (Ed.), Exploring teachers' thinking (pp. 104-124). London: Cassell.

Young, M. (2008). Bringing knowledge back in: From social constructivism to social realism in the sociology of education. London: Routledge.

Young, M., \& Muller, J. (2013). On the powers of powerful knowledge. Review of Education, 1, 229-250. doi: 10.1002/rev3.3017 